\title{
Natural attenuation of chlorobenzene in a deep confined aquifer during artificial recharge process
}

\author{
H. He ${ }^{1,2,3} \cdot$ X. Yu ${ }^{1,2} \cdot$ Y. Huan ${ }^{1,2} \cdot$ W. Zhang ${ }^{1,2}$
}

Received: 27 August 2013/Revised: 20 March 2015/ Accepted: 13 July 2015/Published online: 6 August 2015

(C) Islamic Azad University (IAU) 2015

\begin{abstract}
This paper discusses natural attenuation of chlorobenzene (CB) elimination in a deep confined aquifer in a certain test site in China during a groundwater artificial recharge process. Pilot-scale experiments were conducted in laboratory, including adsorption and biodegradation experiments. The results from the adsorption experiments indicated that the adsorption rate increased within the temperature range $0-20{ }^{\circ} \mathrm{C}$. Processes were fitted to the pseudo-first-order and pseudo-second-order kinetic equations, Freundlich and Langmuir models. Maximal amounts of adsorption were 20.747, 21.505 and $23.364 \mu \mathrm{g} / \mathrm{g}$ at 0,10 and $20^{\circ} \mathrm{C}$, respectively. The adsorption of $\mathrm{CB}$ was an endothermic process. The results from the biodegradation experiments indicated that the processes were well fitted by the Monod and first-order decay kinetics equations at different temperatures. It showed that the Monod $\mu_{\max }$ changed from 0.0314 to $0.0387 \mathrm{~h}^{-1}$, and the half-life $\left(t_{1 / 2}\right)$ decreased from 3.02 to $1.46 \mathrm{~d}$ with an increase in temperature from 0 to $20{ }^{\circ} \mathrm{C}$. The influence of temperature on the biodegradation rate was expressed by the Arrhenius equation. This study provides information on the mechanisms of natural attenuation of $\mathrm{CB}$ in the subsurface environment, whilst also providing the necessary technical
\end{abstract}

W. Zhang

wenjingzhangcn@163.com

1 Key Laboratory of Groundwater Resources and Environment, Ministry of Education, Jilin University, Changchun 130021, China

2 College of Environment and Resources, Jilin University, Changchun 130021, China

3 Shenyang Institute of Geology and Mineral Resources, Shenyang 110000 , China information for the security of artificial recharge implementation.

Keywords Artificial recharge - Groundwater · Chlorobenzene $\cdot$ Adsorption $\cdot$ Biodegradation

\section{Introduction}

Chlorobenzene $(\mathrm{CB})$ is a toxic synthetic chemical that targets multiple organs by all routes of exposure and has been classified as a pollutant of major concern (WHO 2003). It was detected in the drinking water of several US cities at concentrations of $5.6 \mathrm{ppb}$ (USEPA 1995). Additionally, $\mathrm{CB}$ has low-to-moderate systemic toxicity in animals, causing death at moderate-to-high oral doses and at high inhalation concentrations (USEPA 1995). At $20^{\circ} \mathrm{C}$, the vapour pressure and solubility of $\mathrm{CB}$ are $1.33 \mathrm{kPa}$ and $466.3 \mathrm{mg} / \mathrm{L}$, respectively. Evaporation is an important transport process for $\mathrm{CB}$ from water and soil (USEPA 1995). Additionally, CB is 1.1058 times denser than water and therefore has the potential to stay at the bottom of the confined aquifer. Basic and applied research studies have been carried out by environmental protection agencies on the characteristics, contamination situations, environmental behaviour and eco-toxicity of CB. Previous studies have indicated that a large volume of information concerning various aspects of $\mathrm{CB}$ adsorption is available and the study of $\mathrm{CB}$ adsorption is extensive research field from medical, organic chemistry to the geology and so on (Andrzej and Jerzy 1980; Kloprogge et al. 1997). The study of Zhao et al. (2001) showed that the sorption of CB on marine sediment in three media accorded well with the Freundlich model or the Langmuir model, the adsorption reaction parameters could be calculated through the model, and the 
changed trend of concentration could be speculated. The adsorption of $\mathrm{CB}$ properties by different materials have been researched according to the series of experiments, the finer the particle size of the materials, the better the adsorption effect (Long and Li 2010; Guo and Li 2010). The main factor influencing the adsorption of $\mathrm{CB}$ in aquifers was temperature, in a certain temperature range, the higher the temperature, the better adsorption effect (Zhao et al. 2001; Qi et al. 2010; Sennour et al. 2009). In addition, some studies have indicated that $\mathrm{CB}$ could undergo degradation by both photolysis and microbial biodegradation in water and soil (USEPA 1995; Loannis and Dimitrios 2006; Turlough 2008). CB can be partially reduced in the anaerobic zones of aquifers (Magdalena and Jose 2005), and it is also degradable under aerobic conditions (Gerd and Heidrun 2009). The process of microbial biodegradation of $\mathrm{CB}$ could be generalized to Monod model (Ribes et al. 2004; Strigula et al. 2009), and the estimated Monod parameters are useful for predictive modelling of transport ( $\mathrm{Yu}$ et al. 2007). Mohamed and Hatfield (2005, 2011; Mohamed et al. 2006) did a lot of research in microbial degradation of organic pollutants, and the nonlinear model and linear Monod model were used to generalize the process of the degradation; discussed the effects of different factors on microbial degradation of organic pollutants; and forecasted the trend of the change of the concentration by the validated model. Several CBdegrading strains have been isolated (Reineke and Knackmuss 1984; Nishino et al. 1994), and they have been frequently isolated from soil samples with histories of $\mathrm{CB}$ exposure. Batch studies have demonstrated the ability of CB-degrading micro-organisms to remove soil-sorbed CB (Wang and Xi 2008; Brunsbach and Reineke 1994; Van der Meer et al. 1998). Menard and Ramirez (2012) researched the effect of trace gas on the biodegradation of $\mathrm{CB}$, and the results showed that a maximum elimination capacity of 49 $\mathrm{gC} /\left(\mathrm{m}^{3} \mathrm{~h}\right)$ for toluene was achieved for the lowest inlet load of methane. According to mineralization assays in garbage dumps, the degradation rate of $\mathrm{CB}$ was from 31 to 7 days (Lee et al. 2009).

Although many research findings have described the environmental behaviour of $\mathrm{CB}$, most of them focused on $\mathrm{CB}$ adsorption and biodegradation in water and soil. Systematic studies of the natural attenuation of $\mathrm{CB}$ during artificial recharge are rare. Artificial recharge of aquifers is an important water management strategy. The main purpose of this process is to prevent and control land subsidence, to increase the amount of groundwater resources and to prevent seawater intrusion into aquifers. Artificial recharge to aquifers may lead to potential problems, such as the groundwater environment pollution. Organic pollutants in surface water from industry and agriculture are also particular problems, such as CB. If the polluted water was involved in the artificial recharge system, the concentration of $\mathrm{CB}$ in groundwater may be changed. What will happen to $\mathrm{CB}$ in the aquifer, adsorption? biodegradation? or the both? Which one will dominate CB's behavior in the aquifer? It is still hard to answer.

This study focuses on the adsorption and biodegradation behaviour during artificial aquifer recharge in an underground environment. Owing to artificial recharge mostly occurring in summer or winter, the temperature is a major factor that would determine the transformation of $\mathrm{CB}$ in groundwater. Bench-scale batch tests were conducted to investigate adsorption and biodegradation of $\mathrm{CB}$ under different artificial recharge conditions. The results from this study will be used, along with other available information, to provide technical support during artificial aquifer recharge.

\section{Materials and methods}

\section{Site condition}

The study area is about $75,000 \mathrm{~m}^{2}$, located in north-east China (Fig. 1). The key aquifer is the 4th confined aquifer, a homogeneous isotropic aquifer, about $50 \mathrm{~m}$ thick. Aquifer elevation and hydraulic conductivity are $-170 \mathrm{~m}$ and $50 \mathrm{~m} / \mathrm{d}$, respectively, and the hydraulic gradient along the flow direction is about $0.3 \%$.

Considering the economic factors and feasibility, the nearest surface water was selected as recharge water.

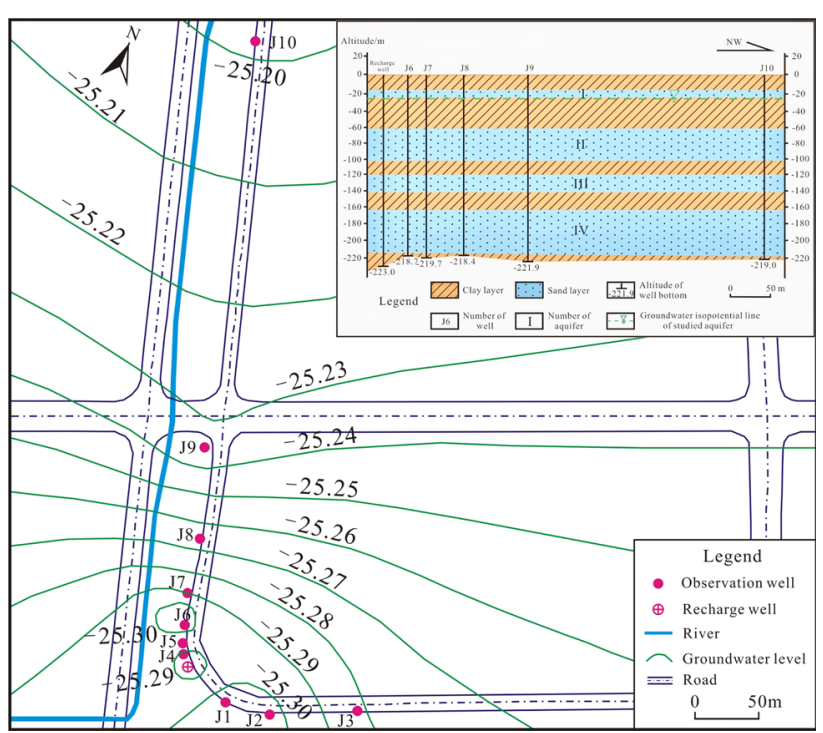

Fig. 1 Schematic diagram of the groundwater is potential line in the fourth confined aquifer 
Table 1 The main chemical components of surface water and groundwater

\begin{tabular}{lllllllllll}
\hline Water & $\mathrm{K}^{+}$ & $\mathrm{Na}^{+}$ & $\mathrm{Ca}^{2+}$ & $\mathrm{Mg}^{2+}$ & $\mathrm{HCO}_{3}^{-}$ & $\mathrm{Cl}^{-}$ & $\mathrm{SO}_{4}{ }^{2-}$ & $\mathrm{NO}_{3}^{-}$ & $\mathrm{TDS}$ & $\mathrm{CB}$ \\
\hline Surface water & 8.94 & 80.88 & 53.72 & 12.38 & 135 & 84.4 & 128.2 & 5.06 & 418 & 42.4 \\
Groundwater & 2.08 & 283.73 & 49.30 & 27.06 & 449 & 276.3 & 13.7 & $<0.05$ & 840 & $<0.01$ \\
\hline
\end{tabular}

The unit of $\mathrm{CB}$ is $\mu \mathrm{g} / \mathrm{L}$, others is $\mathrm{mg} / \mathrm{L}$
However, owing to the increasing development of manufacturing and agriculture, surface water quality has deteriorated, and organic pollution is especially serious. According to the water quality analysis results of surface water and groundwater in Table 1, the groundwater quality of the 4th confined aquifer is good except that chloride and the total dissolved solids exceed the drinking water criteria, the concentration of chlorobenzene $(42.4 \mu \mathrm{g} / \mathrm{L})$ is relatively higher in organic components, and so, the target organic contaminant from the recharge water is CB.

Water and soil samples were collected from the 4th confined aquifer by engineering drilling. They were stored at $4{ }^{\circ} \mathrm{C}$ before use. The physical properties of the soil samples were unit weight $1.546 \mathrm{~g} / \mathrm{cm}^{3}$, specific gravity 2.645 , moisture content $12.392 \%$, porosity 0.414 , and void ratio 0.726 . Their size grading was $11 \%$ for $<0.1 \mathrm{~mm}, 48 \%$ for $0.1-0.25 \mathrm{~mm}$, $33 \%$ for $0.25-0.50 \mathrm{~mm}, 6 \%$ for $0.50-2.0 \mathrm{~mm}$, and $2 \%$ for $>2.0 \mathrm{~mm}$. The soil samples were treated or sterilized, as previously described by Jiang and Zhang (2007).

Recorded statistics shows that the temperature of the 4th confined aquifer is about $20-23{ }^{\circ} \mathrm{C}$ throughout the year, the average is $21.5^{\circ} \mathrm{C}$, whereas the temperature of the recharge water depends on the atmosphere. The maximum $\left(30{ }^{\circ} \mathrm{C}\right)$ and minimum $\left(0{ }^{\circ} \mathrm{C}\right)$ occur in August and January, respectively.

\section{Chemicals}

CB ( $<99 \%$ pure) used in this experiment was obtained from the Pesticide Research Institute of Shenyang, China. The CB stock solution was made up in distilled water up to saturation $\left(466.3 \mathrm{mg} / \mathrm{L}, 20^{\circ} \mathrm{C}\right)$. The initial concentrations for the adsorption and biodegradation experiments were obtained by diluting the stock solution. Samples were filtered immediately through $0.45-\mu \mathrm{m}$ membranes; the second $20 \mathrm{~mL}$ of the filtrate was collected into an Agilent bottle and stored at $4{ }^{\circ} \mathrm{C}$ until analysis. The concentration of $\mathrm{CB}$ in each sample was determined by GC/MS (Agilent 6890/5973N).

\section{Adsorption study}

\section{Batch adsorption experiments}

According to the difference in temperature between groundwater and recharge water, batch adsorption experiments were conducted at serial temperatures $\left(0,10\right.$ and $\left.20{ }^{\circ} \mathrm{C}\right)$ to represent the test temperature occurring during different recharge seasons. To exclude the influence of biodegradation, make sure that the change of concentration of $\mathrm{CB}$ is caused by adsorption; solid samples should be sterilized. According to the adsorption process, the $\mathrm{CB}$ concentration increases during the artificial recharge from the begin to the end; the process of concentration enrichment of $\mathrm{CB}$ made initial concentration of $\mathrm{CB}$ in the experimental procedures larger than the original; due to the studies of Turlough (2008) and Li et al. (2006, 2007), the initial concentration of $\mathrm{CB}$ in the experimental procedures was ten times higher than that in the original recharge water. The initial CB concentration for adsorption kinetics experiments was $466.3 \mu \mathrm{g} / \mathrm{L}$ (obtained by diluting stock solution 1000-fold at indoor temperature). Briefly, $10 \mathrm{~g}$ of soil (dry weight equivalent) and $100 \mathrm{~mL}$ of initial solution in a flask were continuously stirred at $120 \mathrm{rpm}$ in the dark, and the purpose of the design is to simulate the continuous reaction of the adsorption CB during artificial recharge, in order to make experimental conditions more close to aquifer and adequately reaction. The equilibrium time was less than $24 \mathrm{~h}$ according to preliminary studies (Sennour et al. 2009; Zhang et al. 2010). Samples were taken at 1, 2, 4, 6, 8, 10, 12, 18 and $24 \mathrm{~h}$.

According to the results of the adsorption kinetics experiments, the equilibrium times were $8 \mathrm{~h}\left(20^{\circ} \mathrm{C}\right), 10 \mathrm{~h}$ $\left(10{ }^{\circ} \mathrm{C}\right)$ and $12 \mathrm{~h}\left(0{ }^{\circ} \mathrm{C}\right)$, respectively. Subsequent samples were obtained at those three time-points. In order to explore the adsorption efficiency of different concentrations of $\mathrm{CB}$ when it was injected into the aquifer, and calculate the maximum amount of adsorption, different concentration gradient would be designed, and usually the biggest concentration is 100 times of the initial, and the initial concentrations used were 4663, 2331.5, 466.3, 233.15 and $46.63 \mu \mathrm{g} / \mathrm{L}$. The experimental process for isothermal adsorption was the same as described above for the adsorption kinetics experiments.

\section{Data analysis}

The amount of adsorption was calculated according to Eq. (1):

$Q_{t}=\frac{\left(C_{0}-C_{t}\right) V}{W}$

where $C_{O}$ and $C_{t}$ are initial concentration and concentration at time $t, \mu \mathrm{g} / \mathrm{L}$, and $Q_{t}$ is the amount of adsorption at time $t$, $\mu \mathrm{g} / \mathrm{g}$. $V$ is solution volume, $\mathrm{L}$ and $W$ weight of medium, $\mathrm{g}$. 
Two kinetic models, pseudo-first-order (Eq. 2) and pseudo-second-order equations (Eq. 3), were used to analyse the adsorption rate at different temperatures (Zheng and Yang 2004), as shown below:

$\operatorname{Ln}\left(C_{0} / C_{t}\right)=k_{1} t$

$t / Q_{t}=1 / k_{2} Q_{e}^{2}+t / Q_{e}$

where $k_{1}$ and $k_{2}$ are rate constant of pseudo-first-order and pseudo-second-order equation, and $Q_{e}$ is uptake capacity at equilibrium, $\mu \mathrm{g} / \mathrm{g}$. $t$ is time, hour or day, others are the same as above.

Adsorption equilibriums were described by the two classical models of Freundlich and Langmuir (Zhao et al. 2001), as shown below:

$Q_{e}=k_{f} \cdot C_{e}^{n}$

$\frac{C_{e}}{Q_{e}}=\frac{1}{k_{l} q_{m}}+\frac{C_{e}}{q_{m}}$

where $k_{f}$ and $k_{l}$ are coefficient of Freundlich and Langmuir model, $(\mu \mathrm{g} / \mathrm{g})(\mathrm{L} / \mu \mathrm{g})^{n}$ and $\mathrm{L} / \mu \mathrm{g}$, respectively. $n$ is Freundlich model coefficient, $q_{m}$ is Langmuir model coefficient, $\mu \mathrm{g} / \mathrm{g}$ others are the same as above.

\section{Biodegradation study}

\section{Batch biodegradation experiments}

In order to study the influence of temperature on $\mathrm{CB}$ biodegradation, batch biodegradation experiments were conducted at different temperatures $\left(0,10\right.$ and $\left.20^{\circ} \mathrm{C}\right)$. Experiments for biodegradation of $\mathrm{CB}$ were set up as described above for adsorption kinetics experiments, using an initial $\mathrm{CB}$ concentration of $466.3 \mu \mathrm{g} / \mathrm{L}$. Similar to the kinetics experiments, the equilibrium times determined were $7 \mathrm{~d}\left(20{ }^{\circ} \mathrm{C}\right), 9 \mathrm{~d}\left(10^{\circ} \mathrm{C}\right)$ and $12 \mathrm{~d}\left(0{ }^{\circ} \mathrm{C}\right)$, and subsequent samples were obtained at those three time-points. Initial $\mathrm{CB}$ concentrations were the same as in the isothermal adsorption experiments. Micro-organisms are native to the aquifer, and their growth environments were $7 \mathrm{~d}$ $\left(20{ }^{\circ} \mathrm{C}\right), 9 \mathrm{~d}\left(10{ }^{\circ} \mathrm{C}\right)$ and $12 \mathrm{~d}\left(0^{\circ} \mathrm{C}\right)$, respectively. Microorganisms were quantified by absorption (UV-2102C) at $660 \mathrm{~nm}$ and cell densities calculated according to the standard curve.

\section{Data analysis}

$\mathrm{CB}$ biodegradation is a complicated process and the role of micro-organisms is essential. Model equations describing the biodegradation process of $\mathrm{CB}$ should consider the $\mathrm{CB}$ concentration and the density of the micro-organisms. The Monod model with its advantages was adopted (Zhang et al. 2010).
The Monod equation was used to determine the biodegradation rate by different temperatures:

$-\frac{\mathrm{d} C}{\mathrm{~d} t}=\frac{\mu_{\max } \cdot B \cdot C_{t}}{k_{s}+C_{t}}$

In order to fit curve more intuitive, the equation was linearly transformed to:

$\frac{B}{\Delta}=\frac{k_{S}}{\mu_{\max }} \cdot \frac{1}{C_{t}}+\frac{1}{\mu_{\max }}, \Delta=\frac{\mathrm{d} C}{\mathrm{~d} t} \approx \frac{\Delta C}{\Delta t}$

where $\mu_{\max }$ is Monod maximum-specific utilization rate, $\mathrm{h}^{-1}, k_{s}$ is Monod half-saturation coefficient, $\mu \mathrm{g} / \mathrm{L}$, and $B$ is concentration of micro-organism, $\mu \mathrm{g} / \mathrm{L}$, others are the same as above.

Several investigations (Paul et al. 2001; Malzer et al. 1993) have shown that the overall kinetics can be described by the first-order decay kinetics equation:

$C_{t}=C_{0} \cdot e^{-\lambda t}$

CB half-life was calculated using the empirical formula:

$t_{1 / 2}=\frac{0.693}{\lambda}$

where $t_{1 / 2}$ is half-life of biodegradation, day, and $\lambda$ is biodegradation rate constant. Others are the same as above.

\section{Results and discussion}

\section{Adsorption}

\section{Adsorption kinetics}

The adsorption curves of $\mathrm{CB}$ are shown in Fig. 2. The equilibrium times obtained were $8 \mathrm{~h}\left(20^{\circ} \mathrm{C}\right), 10 \mathrm{~h}\left(10^{\circ} \mathrm{C}\right)$ and $12 \mathrm{~h}\left(0^{\circ} \mathrm{C}\right)$, respectively. We observed that the higher the temperature, the smaller the adsorption equilibrium time of the $\mathrm{CB}$. At the equilibrium time, $C_{t} / C_{0}$ was 0.35 $\left(20{ }^{\circ} \mathrm{C}\right), 0.46\left(10^{\circ} \mathrm{C}\right)$ and $0.56\left(0^{\circ} \mathrm{C}\right)$, respectively, which indicates that the higher the temperature, the greater the

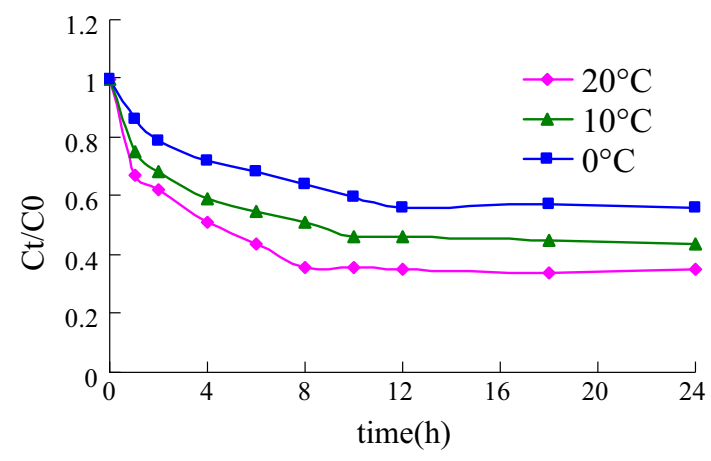

Fig. 2 Effect of different temperatures on adsorption of CB 
Table 2 Kinetic coefficients of pseudo-first-order and pseudosecond-order equations at different temperatures

\begin{tabular}{lllllll}
\hline Temperature $\left({ }^{\circ} \mathrm{C}\right)$ & \multicolumn{2}{l}{ Pseudo-first-order equation } & & & \multicolumn{2}{l}{ Pseudo-second-order equation } \\
\cline { 2 - 3 } & $k_{1}$ & $R^{2}$ & & $k_{2}$ & $R^{2}$ & $Q_{e}(\mu \mathrm{g} / \mathrm{g})$ \\
\hline 20 & 0.0882 & 0.9979 & & 0.27 & 0.9921 & 3.27 \\
10 & 0.0513 & 0.9739 & & 0.23 & 0.9857 & 2.70 \\
0 & 0.0365 & 0.9794 & & 0.18 & 0.9861 & 2.24 \\
\hline
\end{tabular}

amount of CB adsorbed. Because CB adsorption was an endothermic reaction, higher temperature promotes the adsorption reaction, which is in agreement with a previous study (Cornelissen and Hassell 2000). According to the results adsorption reaction will be promoted from winter to summer, so the amount of adsorbed will be larger, and the concentration of $\mathrm{CB}$ in the aquifer will be declined.

The results showed that the adsorption of $\mathrm{CB}$ was well fitted to the pseudo-first-order and pseudo-second-order equations, respectively. We compared the two kinetic equations and summarized the main coefficients in Table 2. When temperature ranged from 0 to $20{ }^{\circ} \mathrm{C}, k_{1}$ and $k_{2}$ increased from 0.0365 to 0.0882 and from 0.18 to 0.27 , respectively. This indicated that, as temperature increased, the reaction rates were also accelerated, with rise in $Q_{e}$ from 2.24 to 3.27. So temperature was the driving factor in the adsorption of CB (Zheng and Yang 2004). The correlation coefficient $R^{2}$ of pseudo-second-order equation is a bit larger than pseudo-first-order equation, and $Q_{e}$ was calculated by pseudo-second-order equation rather than pseudo-first-order equation, so pseudo-second-order equation is better for the study of adsorption.

\section{Isothermal adsorption}

CB adsorption isotherms are shown in Figs. 3 and 4. At equilibrium concentrations between 0 and $3500 \mu \mathrm{g} / \mathrm{L}$, the adsorption of CB could be described by the Freundlich and Langmuir models. By comparing the two isothermal adsorption models, the main coefficients are summarized in Table 3.

In the Freundlich and Langmuir models, temperature ranged from 0 to $20^{\circ} \mathrm{C}, k_{f}$ ranged from 0.0324 to 0.1077 , and $k_{l}$ ranged from 0.4161 to 0.9820 . It indicated that as temperature increased, the amounts of CB adsorbed were increased to equilibrium. However, at the maximal amount of adsorbed $\mathrm{CB}, q_{m}$ in the Langmuir model ranged from 20.747 to $23.364 \mu \mathrm{g} / \mathrm{g}$, and coefficient $n$ in the Freundlich model ranged from 0.7359 to 0.6527 . A value of $n$ close to 1.00 suggested that the adsorption isotherm was linearly dependent on the concentration of the adsorbent. Due to the concentration range employed in this study, a linear model was not suitable for estimating the soil/water distribution coefficient $\left(k_{d}\right)$. Hence, the $k_{d}$ was calculated from the

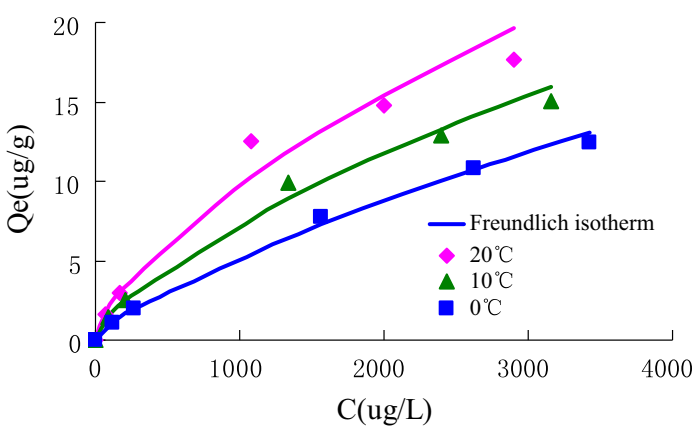

Fig. 3 Freundlich adsorption isotherm

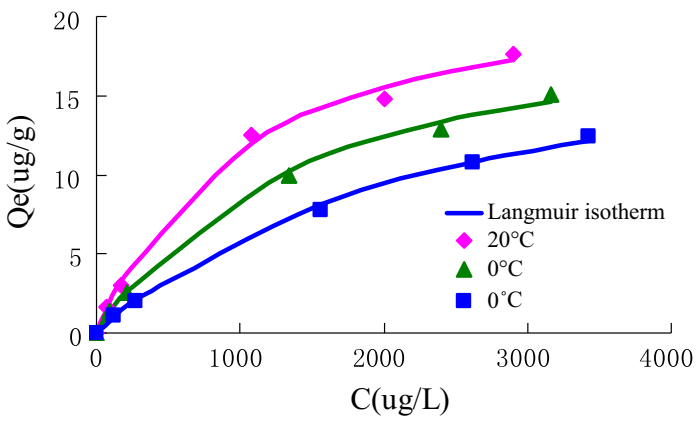

Fig. 4 Langmuir adsorption isotherm

entire dataset (Xu et al. 2009): $5.7\left(20^{\circ} \mathrm{C}\right), 4.5\left(10^{\circ} \mathrm{C}\right)$ and $3.5 \mathrm{~L} / \mathrm{kg}\left(0{ }^{\circ} \mathrm{C}\right) . k_{\mathrm{oc}}$ obtained from the equation:

$k_{\mathrm{oc}}=k_{d} / f_{\mathrm{oc}}$

where $k_{\mathrm{oc}}$ is the organic carbon adsorption coefficient, $\mathrm{L} / \mathrm{kg}$, and $f_{\text {oc }}$ is the organic carbon content of the soil. Therefore, $\lg \left(k_{\mathrm{oc}}\right)$ was $3.38\left(20^{\circ} \mathrm{C}\right), 3.28\left(10^{\circ} \mathrm{C}\right)$ and $3.17\left(0{ }^{\circ} \mathrm{C}\right) \mathrm{L} / \mathrm{kg}$ at different temperature. The value of $\lg \left(k_{\mathrm{oc}}\right)$ and $k_{d}$ indicated that $\mathrm{CB}$ possessed a high adsorption affinity for the fourth confined aquifer soil. The comparison of adsorption affinity at different temperatures suggested high temperature increased the affinity of CB with the aquifer soil, which is in agreement with the results of the previous study of Zhao et al. (2001). Interestingly, the $\lg \left(k_{\mathrm{oc}}\right)$ of $\mathrm{CB}\left(3.38\right.$ at $\left.20{ }^{\circ} \mathrm{C}\right)$ in this study was similar to a previously published result $2.72-3.55$ (Zhao et al. 2001), and the $k_{d}$ of $\mathrm{CB}\left(4.5\right.$ at $\left.10{ }^{\circ} \mathrm{C}\right)$ was lower than the result of Zhao et al. (2001) (4.87-5.36). When the temperature was increased from 0 to $20^{\circ} \mathrm{C}, \Delta H$ was calculated by the Van't Hoff equation: 
Table 3 Coefficients of the Freundlich and Langmuir models at different temperatures

\begin{tabular}{llllllll}
\hline Temperature $\left({ }^{\circ} \mathrm{C}\right)$ & \multicolumn{2}{l}{ Freundlich model } & & & \multicolumn{4}{l}{ Langmuir model } \\
\cline { 2 - 3 } & $k_{f}\left[(\mu \mathrm{g} / \mathrm{g})(\mathrm{L} / \mu \mathrm{g})^{n}\right]$ & $n$ & $R^{2}$ & & $k_{l}(\mathrm{~L} / \mu \mathrm{g})$ & $q_{m}(\mu \mathrm{g} / \mathrm{g})$ & $R^{2}$ \\
\hline 20 & 0.1077 & 0.6527 & 0.9880 & 0.9820 & 23.364 & 0.9891 \\
10 & 0.0664 & 0.6803 & 0.9962 & 0.6738 & 21.505 & 0.9905 \\
0 & 0.0324 & 0.7359 & 0.9989 & & 0.4161 & 20.747 & 0.9835 \\
\hline
\end{tabular}

$\lg k_{d 2}=\lg k_{d 1}-\frac{\Delta H}{2.3 R}\left(\frac{1}{T_{2}}-\frac{1}{T_{1}}\right)$

where $k_{d 1}$ and $k_{d 2}$ are the distribution coefficient at temperature $T_{1}$ and $T_{2}, \mathrm{~L} / \mathrm{kg}$, respectively. $T_{1}$ and $T_{2}$ are the reference and the target temperature, K. $\Delta H$ is enthalpy, $\mathrm{J} / \mathrm{mol}$.

$\Delta H$ equals $16.77 \mathrm{~kJ} / \mathrm{mol}, \Delta H>0$; therefore, the adsorption of $\mathrm{CB}$ was an endothermic process. When temperature was increased, promoting the process to the positive direction, the amount of $\mathrm{CB}$ adsorption and rate of adsorption was increased.

\section{Biodegradation}

\section{Monod biodegradation}

CB biodegradation experiments can be described using the Monod equation (Zhang et al. 2010) shown in Fig. 5. CB was rapidly degraded on the first day, but the degradation rate decreased over time. Since biodegradation is a relatively slow process, the decrease of $\mathrm{CB}$ is effort from adsorption at the equilibrium time. The concentration of microbes increased sharply and then slowed; as microbes were using the $\mathrm{CB}$ as the sole carbon source, the sudden increasing of carbon source makes the microbe multiply rapidly, and then, the growth tends to slow. Higher temperatures promoted the growth of microbes, so the equilibrium times were $12 \mathrm{~d}\left(0{ }^{\circ} \mathrm{C}\right), 9 \mathrm{~d}\left(10{ }^{\circ} \mathrm{C}\right)$ and $7 \mathrm{~d}$ $\left(20{ }^{\circ} \mathrm{C}\right) ; 20{ }^{\circ} \mathrm{C}$ was the optimal temperature for microbial growth of the three temperatures tested, because the increase in temperature provides energy for microbes. Monod model parameters are summarized in Table 4.

In Monod equation, $\mu_{\max }$ is related to the microbial activity, and $k_{s}$ indicated the affinity of the substrate to micro-organisms (Bruce and Perry 2002). These results show that $\mu_{\max }$ changed with temperature. From 0 to $20^{\circ} \mathrm{C}, \mu_{\max }$ was increased from 0.0314 to $0.0387 \mathrm{~h}^{-1}$. According to this result, it indicated that microbial activity is fine under high temperature condition. However, it is well known that if the temperature is too high, microbes may die. Then the growth of microbes will be promoted within a reasonable temperature range. As the substrate used in these experiments was always $\mathrm{CB}$, the values of $k_{s}$ did not change significantly, and stable carbon source
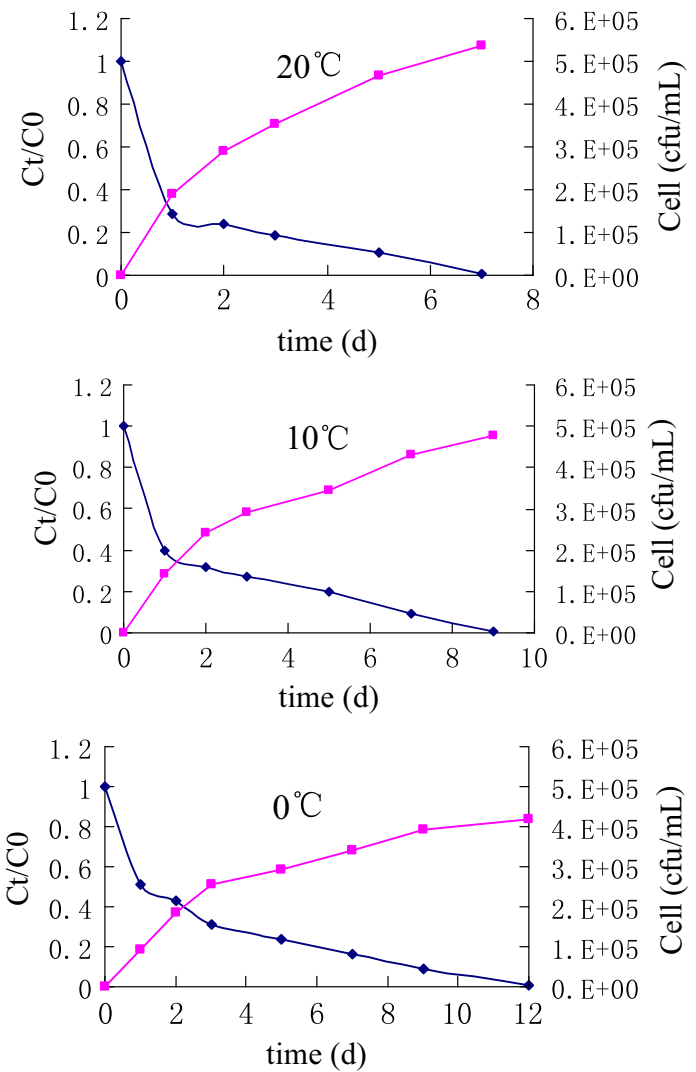

Fig. 5 Monod biodegradation at different temperatures

Table 4 Monod parameters at different temperatures

\begin{tabular}{llll}
\hline Temperature $\left({ }^{\circ} \mathrm{C}\right)$ & $q_{\max }\left(\mathrm{h}^{-1}\right)$ & $k_{s}(\mu \mathrm{g} / \mathrm{L})$ & $R^{2}$ \\
\hline 20 & 0.0387 & 293.06 & 0.9962 \\
10 & 0.0351 & 296.48 & 0.9882 \\
0 & 0.0314 & 295.93 & 0.9889 \\
\hline
\end{tabular}

ensured the microbial growth rate. As temperature was increased, microbial activity was influenced, consequently, the value of $\mu_{\max }$ changed.

\section{Biodegradation kinetics}

The process of biodegradation can also be described by the kinetics equation. Figure 6 shows that as temperature 


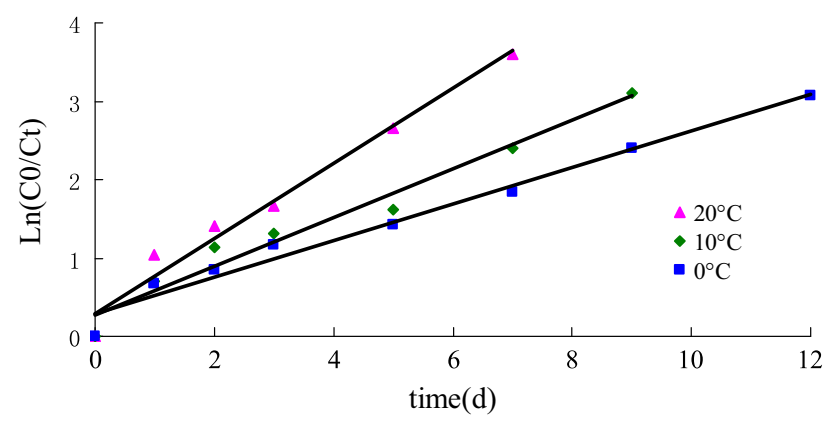

Fig. 6 Biodegradation kinetics at different temperatures

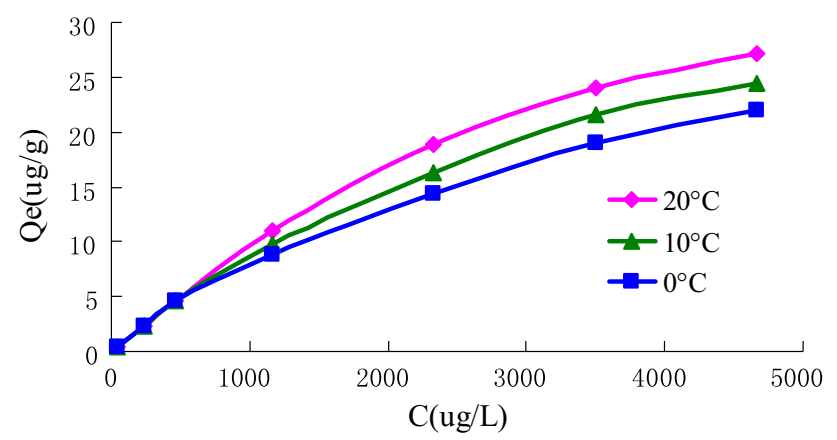

Fig. 7 The effect of different concentrations on biodegradation rate

ranged from 0 to $20{ }^{\circ} \mathrm{C}, \lambda$ ranged from 0.2291 to 0.4757 $\mathrm{d}^{-1}$ and $t_{1 / 2}$ ranged from 3.02 to $1.46 \mathrm{~d}$. This indicates that the rate of biodegradation was increased at higher temperature, so $t_{1 / 2}$ was reduced. The biodegradation of CB was fitted to the decay kinetics equation, but as the $R_{\min }^{2}$ of Monod was 0.9882 and the $R_{\max }^{2}$ of the decay kinetics was 0.9769 , the Monod equation was better fitted to our data, in agreement with Zhang et al. (2010). The influence of temperature on CB biodegradation could be expressed by Arrhenius equation:

$\lambda=A e^{-\frac{E_{a}}{R T}}$

where $A$ is Arrhenius law coefficient, $E_{a}$ is biodegradation activation energy, $\mathrm{kJ} / \mathrm{mol}, R$ is the ideal gas constant, $8.3145 \mathrm{~J} \mathrm{~mol}^{-1} \mathrm{~K}^{-1}$, others are the same as above.

$A$ was 9752.7 and $E_{a}$ was $24.27 \mathrm{~kJ} / \mathrm{mol}$; the equation was described as $\lambda=9752.7 e^{-\frac{2918.6}{T}}, T$ was less than $30{ }^{\circ} \mathrm{C}$ during all seasons, and the higher the temperature, the larger the coefficient.

Figure 7 shows the amount of biodegradation at different concentrations of $\mathrm{CB}$. The $Q_{e}$ of $\mathrm{CB}$ was $20>10>0{ }^{\circ} \mathrm{C}$ and the maximal amount of biodegradation was about $28.32,26.41$ and $23.77 \mu \mathrm{g} / \mathrm{g}$, respectively.

From the adsorption experiments, we know $q_{m}$ in the Langmuir model ranged from 20.747, 21.505 to $23.364 \mu \mathrm{g} /$ $\mathrm{g}$, and the maximal amount of biodegradation was about 23.77, 26.41 and $28.32 \mu \mathrm{g} / \mathrm{g}$ at $0, \quad 10$ and $20^{\circ} \mathrm{C}$, respectively. Therefore, the effect of $\mathrm{CB}$ biodegradation was better than that of adsorption.

\section{Conclusion}

This study systematically discussed the adsorption and biodegradation of $\mathrm{CB}$ in a groundwater artificial recharge programme. The adsorption of $\mathrm{CB}$ was fitted to the Freundlich and Langmuir models. Over a temperature range from 0 to $20{ }^{\circ} \mathrm{C}$, the adsorption rate increased and the highest amount of adsorption obtained was $23.364 \mu \mathrm{g} / \mathrm{g}$. The adsorption of $\mathrm{CB}$ was an endothermic process. The biodegradation of $\mathrm{CB}$ was fitted to the Monod equation. When the temperature was raised, the biodegradation rate increased and the highest amount of biodegradation obtained was $28.32 \mu \mathrm{g} / \mathrm{g}$. The influence of temperature on biodegradation was expressed by Arrhenius equation. The effect of $\mathrm{CB}$ biodegradation was better than that of adsorption. The best season for artificial recharge is summer, as higher rates of adsorption and biodegradation of $\mathrm{CB}$ are obtained at higher temperatures, which will reduce the leaching potential of this toxic chemical.

Acknowledgments The research was financially supported by National Natural Science Foundation of China (41103045, 41472215). The authors would like to thank the journal editors and the reviewers for their comments which helped to improve the paper considerably. We are also thankful to the staff at Shanghai Institute of Geological Survey for their assistance in the field.

\section{References}

Andrzej C, Jerzy S (1980) The adsorption of chlorobenzene on the gold electrode. Electrochim Acta 25:1313-1316

Bruce R, Perry M (2002) Environmental biotechnology: principles and applications. McGraw-Hill Companies Inc, New York, pp $128-135$

Brunsbach FR, Reineke W (1994) Degradation of chlorobenzenes in soil slurry by a specialized organism. Appl Microbiol Biotechnol 42:4125-4420

Cornelissen G, Hassell KA (2000) Slow desorption of PCBs and chlorobenzenes from soils and sediments: relations with sorbent and sorbate characteristics. Environ Pollut 108:69-80

Gerd UB, Heidrun P (2009) Pulsed gas injection: a minimum effort approach for enhanced natural attenuation of chlorobenzene in contaminated groundwater. Environ Pollut 157:2011-2018

Guo Y, Li Y (2010) Effects of activated carbon properties on chlorobenzene adsorption and adsorption product analysis. Chem Eng J 236:506-512

Jiang J, Zhang R (2007) Simultaneous biodegradation of methyl parathion and carbofuran by a genetically engineered microorganism constructed by mini-Tn5 transposon. Biodegradation 18:403-412

Kloprogge JT, Korbijn L, Koster TM (1997) Head-space gas chromatography, a quick and simple method to screen adsorption capabilities of porous materials: adsorption of chlorobenzene on modified montmorillonite. Appl Clay Sci 12:85-91 
Lee S, Pardue JH, Moe WM (2009) Effect of sorption and desorptionresistance on biodegradation of chlorobenzene in two wetland soils. J Hazardous Mater 161:492-498

Li L, Peters CA, Celia MA (2006) Upscaling geochemical reaction rates using pore-scale network modeling. Adv Water Resour 29(9):1351-1370

Li L, Peters CA, Celia MA (2007) Applicability of averaged concentrations in determining geochemical reaction rates in heterogeneous porous media. Am J Sci 307:1146-1166

Loannis P, Dimitrios K (2006) Influence of soil physicochemical and biological properties on the degradation and adsorption of the nematicide fosthiazate. J Agri Food Chem 54:6783-6789

Long C, Li Q (2010) Adsorption characteristics of benzenechlorobenzene vapour on hypercrosslinked polystyrene adsorbent and a pilot-scale application study. Chem Eng J 160:723-728

Magdalena VM, Jose RE (2005) Degradation of chlorobenzenes by a strain of acidovoraxavenae isolated from a polluted aquifer. Chemosphere 61:98-106

Malzer HJ, Gerlach M, Gimbel R (1993) Effects of shock loads on bank filtration and their prediction by control filters. Water Supply $11: 165-177$

Menard C, Ramirez AA (2012) Effect of trace gases, toluene and chlorobenzene, on methane biofiltration: an experimental study. Chem Eng J 204:8-15

Mohamed M, Hatfield K (2005) Modeling microbial-mediated reduction using the quasi-steady-state approximation. Chemosphere 59:1207-1217

Mohamed M, Hatfield K (2011) Dimensionless monod parameters to summarize the influence of microbial inhibition on the attenuation of groundwater contaminants. Biodegradation 22:877-896

Mohamed M, Hatfield K, Hassan AE (2006) Monte Carlo evaluation of microbial-mediated contaminant reactions in heterogeneous aquifers. Adv Water Resour 29:1123-1139

Nishino SF, Jim CS, Charles AP (1994) Biodegradation of chlorobenzene by indigenous bacteria. Environ Toxicol Chem 13:871-877

Paul S, Boric H, Worth E (2001) Investigations of the relevance of aliphatic amines for drinking water production from Elbe riverbank filtrate. VomWasser 96:29-42

Qi C, Li F, Li Y (2010) Adsorption characteristics of benzenechlorobenzene vapour on hypercrosslinked polystyrene adsorbent and a pilot-scale application study. Chem Eng J 160:723-728
Reineke W, Knackmuss HJ (1984) Microbial metabolism of haloaromatics: isolation and properties of chlorobenzene-degrading bacterium. Appl Environ Microbiol 47:395-402

Ribes J, Keesman K, Spanjers H (2004) Modeling anaerobic biomass growth kinetics with a substrate threshold concentration. Water Res 38(20):4502-4510

Sennour R, Mimane G, Benghalem A (2009) Removal of the persistent pollutant chlorobenzene by adsorption onto activated montmorillonite. Appl Clay Sci 43:503-506

Strigula N, Detteb H, Melasc VB (2009) A practical guide for optimal designs of experiments in the Monod model. Environ Model Softw 24(9):1019-1026

Turlough FG (2008) Ex-situ bioremediation of chlorobenzenes in soil. J Hazard Mater 154:9-20

USEPA (1995) OPPT chemical fact sheet-chlorobenzene fact sheet (CAS No. 108-90-7) U.S. Environmental Protection Agency, Washington, DC

Van der Meer JR, Werlen C, Nishino SF (1998) Evolution of a pathway for chlorobenzene metabolism leads to natural attenuation in contaminated groundwater. Appl Environ Microbiol 64:4185-4193

Wang C, Xi J (2008) Biodegradation of gaseous chlorobenzene by white-rot fungus phanerochaete chrysosporium. Biomed Environ Sci 21:474-478

WHO (2003) Chlorobenzene (Environmental Health Criterion 169). WHO, Geneva

$\mathrm{Xu} \mathrm{J}$, Chen WP, Wu LS (2009) Adsorption and degradation of ketoprofen in soils. J Environ Qual 38:1177-1182

Yu J, Molstad L, Frostegard A, Aagaard P, Breedveld GD, Bakken LR (2007) Kinetics of microbial growth and degradation of organic substrates in subsoil as affected by an inhibitor, benzotriazole: model based analyses of experimental results. Soil Biol Biochem 39(7):1597-1608

Zhang W, Lin X, Su X (2010) Transport and fate modeling of nitrobenzene in groundwater after the Songhua River pollution accident. J Environ Manag 91:2378-2384

Zhao X, Yang G, Wu P, Li N (2001) Studies on the adsorption of chlorobenzene on marine sediments. J Colloid Interface Sci 243:273-279

Zheng S, Yang Z (2004) Removal of chlorophenols from groundwater by chitosan sorption. Water Res 38:2315-2322 